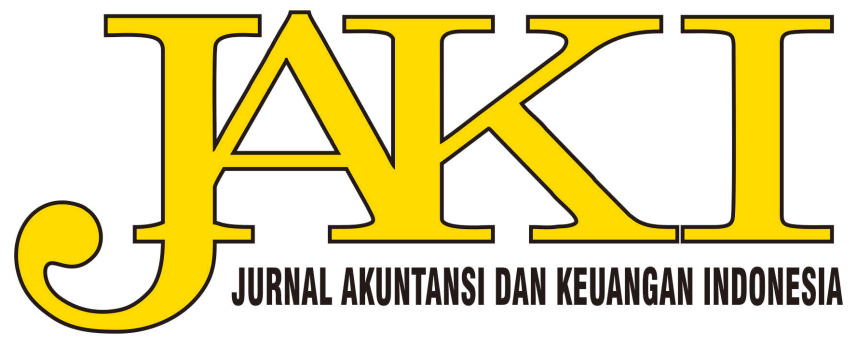

Volume 17

Issue 1 Volume 17, Issue 1, 2020

Article 5

$6-30-2020$

\title{
INTERNAL CONTROL PRACTICES OF MOSQUES IN JAVA, INDONESIA
}

Nining Islamiyah

International Islamic University Malaysia

Siti Alawiah Siraj

International Islamic University Malaysia

Ahmad Zamri Osman

International Islamic University Malaysia

Follow this and additional works at: https://scholarhub.ui.ac.id/jaki

Part of the Accounting Commons, Corporate Finance Commons, Finance and Financial Management Commons, and the Taxation Commons

\section{Recommended Citation}

Islamiyah, Nining; Siraj, Siti Alawiah; and Osman, Ahmad Zamri (2020) "INTERNAL CONTROL PRACTICES OF MOSQUES IN JAVA, INDONESIA," Jurnal Akuntansi dan Keuangan Indonesia: Vol. 17: Iss. 1, Article 5. DOI: $10.21002 /$ jaki.2020.05

Available at: https://scholarhub.ui.ac.id/jaki/vol17/iss1/5

This Article is brought to you for free and open access by the Faculty of Economics \& Business at UI Scholars Hub. It has been accepted for inclusion in Jurnal Akuntansi dan Keuangan Indonesia by an authorized editor of UI Scholars Hub. 
Jurnal Akuntansi dan Keuangan Indonesia

Volume 17 Nomor 1, Juni 2020

\title{
INTERNAL CONTROL PRACTICES OF MOSQUES IN JAVA, INDONESIA
}

\author{
Nining Islamiyah \\ Postgraduate, Department of Accounting, \\ Kulliyyah of Economics and Management Sciences, \\ International Islamic University Malaysia \\ nining.islamiyah@gmail.com \\ Siti Alawiah Siraj \\ Department of Accounting, Kulliyyah of Economics and Management Sciences, \\ International Islamic University Malaysia \\ s.alawiah@iium.edu.my \\ Ahmad Zamri Osman \\ Department of Accounting, Kulliyyah of Economics and Management Sciences, \\ International Islamic University Malaysia \\ azamrio@iium.edu.my
}

\begin{abstract}
Internal controls are necessary tools to help organizations attain their organizational goals. Lack of these controls in any type of organizations could lead to fraudulent activities, which consequently may hamper the achievement of organizational goals. This study aims to investigate the internal control practices in two Indonesian mosques; Mosque A and Mosque B. The study employed the Committee of Sponsoring Organization (COSO, 2013) framework of internal controls to frame the investigation of internal control practices in these two mosques. Data collection was undertaken through interviews and reviews of relevant documents. The findings revealed that the two selected mosques, Mosque A and Mosque B, have the five internal control practices in place. These include control environment, risk assessment, control activities, information and communication, and monitoring activities. This study concludes that internal control practices are a necessary process to support the accountability of the mosque. The results may be used as a potential reference for improving internal control practices in the Indonesian mosques.
\end{abstract}

Keywords: internal control practices, fraudulent activities, mosques, accountability

\begin{abstract}
Abstrak
Pengendalian internal merupakan alat yang diperlukan oleh organisasi untuk membantu dalam mencapai tujuannya. Kurangnya pengendalian dapat menyebabkan terjadinya aktivitas kecurangan yang dapat menghambat tercapainya tujuan organisasi. Oleh karena itu, penelitian ini bertujuan untuk mengetahui bagaimana praktik pengendalian internal yang dilakukan oleh masjid di Indonesia. Dua masjid dipilih untuk tujuan penelitian ini, yaitu Masjid A dan Masjid B. Penelitian ini menggunakan kerangka pengendalian internal dari Committee of Sponsoring Organization (COSO 2013) sebagai acuan untuk meneliti praktik pengendalian internal di kedua masjid tersebut.
\end{abstract}


Pengumpulan data dilakukan melalui wawancara dan tinjauan dokumen yang relevan. Hasil dari penelitian ini mengungkapkan bahwa dua masjid terpilih; Masjid A dan B, memiliki lima mekanisme praktik pengendalian internal. Mekanisme tersebut meliputi lingkungan pengendalian, penilaian risiko, kegiatan pengendalian, informasi dan komunikasi, dan kegiatan pemantauan. Selain itu, penelitian ini juga menyimpulkan bahwa praktik pengendalian internal merupakan proses yang diperlukan untuk mendukung akuntabilitas masjid. Hasil dari penelitian ini dapat digunakan sebagai referensi yang potensial untuk memperbaiki praktik pengendalian internal pada masjid di Indonesia.

\section{Kata kunci: praktik pengendalian internal, aktivitas kecurangan, masjid, akuntabilitas}

\section{INTRODUCTION}

Internal control is primarily a series of operational and information systems that would ensure the attainment of organizational goals (Mintzberg 1989). Compliance with relevant laws, rules and regulations, and procedures embedded in the controls could improve operational efficiency and effectiveness of organizations (Bongani, 2013).

Nonprofit organizations (NPOs) are without exception in requiring internal controls as part of their organizational systems. Their main activities, which involve delivering religious, social and charity services, are generally aimed at improving the welfare of diverse communities. The environment and main activities in which these organizations are operating may be seen as they would be less likely to be involved in cheating, thefts, swindling or corruptions. Unfortunately, many reported cases showed these types of organizations have no immunity against these fraudulent activities. Thefts, embezzlement of resources, misconduct among employees and even members of the Board, misrepresentation of financial statements, and corruption are commonly reported cases (Seyam et al., 2018). A study conducted by McKeever (2018) reported frauds involving approximately US\$40-45billions in nonprofit organizations from 2007-2010, and these figures have surpassed US\$ 67 billion in 2013. The Association of Certified Fraud Examiners (2018) has also reported that nonprofit organizations accounted for around nine percent
(9\%) of the fraud and incurred an average loss of US\$75,000.

Regrettably, fraud cases are also reported to rampantly occur in mosques, which are regarded as sacred in Islam. Allegations of employees or volunteers defrauding mosques funds and assets quite regularly cover community news. For instance, there was a case in Singapore where a woman swindled around S\$38,000 from the mosque fund between 2017 and 2019 (Lam, 2020). In Malaysia, RM 1 million (USD 236,630) of mosque funds was reported being misappropriated in the course of procuring carpets for the mosque (mstar.com, 2016). Similar misappropriations of mosque funds were also reported in mosques across Indonesia. For instance, the Chairperson of the South Sulawesi Grand Mosque Foundation, Syarifuddin Daud, was arrested on suspicion of swindling IDR 5 billion (USD 354,912) of the Great Mosque's fund (Padmasari, 2018). In 2019, a total collection of IDR 55 million (USD 3,904) meant for constructing a mosque after an earthquake in West Nusa Tenggara was misappropriated (Pratama, 2019). In another case, the Indonesia's Corruption Eradication Commission (Komisi Pemberantasan Korupsi) oversees several suspected corruption cases related to the Great Melawi Mosque construction. This state development project lost around IDR 5 billion (USD 354,912) (Rachman, 2019). Unfortunately, there are still many misappropriation cases involving mosque funds are not reported. These reported cases of misconduct involving substantial amount of public 
monies, primarily meant for the community welfare, giving an alarming signal of a vulnerable situation within the mosque administration to fraudulent activities and thus necessitates an investigation into the state of its internal control system.

Thus, this paper aims to discuss mosques' the existing internal control practices mosques in Java. The study selected two mosques, which are considered active as they are conducting a wide range of religious programs and delivering welfare activities. One of the mosques was chosen to be a pilot mosque for the financial management of mosques program in Indonesia, which has been recognised with several awards from Indonesian institutions. The paper is organized into eight sections. It introduces the study in the first section and followed by a brief description of mosques in Indonesia. The third section discusses prior studies on internal controls and subsequently elaborates on the mechanism of accountability that outlines this study. The research method, including the cases, data collection and analysis is presented in Section Five. Section Six describes the internal control practices of the two selected Javanese mosques and followed by the general observation of accountability mechanisms in the two mosques. Section Eight concludes the paper.

\section{LITERATURE REVIEW}

\section{Mosques in Indonesia}

NPOs have unique features in terms of funding. Some nonprofit organizations rely heavily on the government (Hall 2002), while others resource to membership dues and donations. Islamic nonprofit organizations, which are religious-based such as mosques, however, would also receive givings such as infaq (non-obligatory charity), zakat (obligatory charity), and waqf (endowment) to be part of their funding. In Indonesia, some mosques have also established the Baitul Mal wat Tamwil (BMT), a cooperative entity, operating to provide financial assistance to the community. With diverse sources and substantial amounts of funds, it is quite a challenge for mosques to deal with fraudulent activities due to its nature and the way they are operating the activities.

In some cases, nonprofit organizations face financial restrictions, and thus inevitably hire unpaid managers who have very little or sometimes no knowledge in financial management (Greenlee et al. 2007). Mosques, unfortunately, suffer the same problems of financial limitations and hiring managers who are lacking in specific financial management skills but undertaking critical financial management duties. This situation could trigger the creation of a magnet of fraud. In addition, the customary practices within religious organizations of relying on trust have weakened internal control, and together with laxity of business and financial knowledge puts them in a more vulnerable state to engage in fraudulent activities (Kummer et al. 2014).

Indonesia, as the world's largest Muslim country, has approximately 731,096 mosques as of 2013 (Fahmi 2018). Mosques always have a significant role in people's lives in this Muslim country. Their lives, which are revolving within and around mosques, compel them to donate generously to support mosques' diverse activities. For instance, one of the mosques in Indonesia is able to secure a total collection of infaq around IDR 200 million (US\$14,196) a month. This sum does not include receipts in the form of zakat, waqf, and other types of givings and donations. It is inconceivable how much funds are received by all mosques across Indonesia. Undoubtedly, the massive amount of funds handled by the mosques demands an effective internal control system to ensure the objectives of serving the community, which simultaneously fulfills the altruistic intention of contributors, donors and endowers are achieved. The presence of a good internal control system could improve the effectiveness and efficiency of the organization's operational activities 
(AICPA 1994). More importantly, the existence of internal control practices would also help to prevent fraudulent activities in mosques.

\section{Studies in Internal Control}

Internal control is one of the critical elements of organizations. According to the Committee of Sponsoring Organization (COSO 2013), there are five integrated components of internal control: control environment, risk assessment, control activities, information and communication, and monitoring activities. Firstly, the control environment establishes the foundation for other components, which include action, policies, and procedures in the organizations. Secondly, a risk assessment undertakes the assessing processes to identify the methods for managing risks. In the risk assessment, the management needs to think about the possible change that may influence the organizational environment and means to potentially manage the effect. Thirdly, control activities are policies and procedures, which guarantee the management policies are undertaken correctly and minimize the risks. Fourthly, the first component of information is obtained or generated by the management from internal and external sources to support internal control components. The information system acts as a method to identify, arrange, analyze, classify, recognize, and report the transactions and safeguard the asset and liabilities. Hence, the second component of communication is a process to understand each of the administrator's roles and responsibilities, which are related to internal controls in financial reporting. The communication may be expressed verbally or an action undertaken by the management (Tarigan and Saputra 2013). Fifthly, monitoring is a process of determining the performance quality of the internal control processes over time and is used for correcting any malfunctioning processes. Monitoring could be implemented by the external auditor or the controller in the internal control system
(Agoes 2012). These components work to establish the foundation for good internal control within organizations.

Several studies have been conducted on internal control practices in nonprofit organizations, including mosques. In terms of internal control aspects, Kamaruddin and Ramli (2017) studied three Islamic nonprofit organizations with similar characteristics in Malaysia. The study reported several similarities in internal control practices aspects, including segregation of duties, authorization of transactions, and documentation of records in each of the organizations. However, these organizations have different practices in physical control of assets and the recording of transactions. In addition, the study reported some challenges in the internal control practices, such as lack of financial personnel, low equipped physical control tools, and not assigning internal auditors to evaluate the activities and financial limitation. Besides, two out of the three Islamic nonprofit organizations did not practice the internal control process for assessing the performance.

On the other hand, Masrek et al. (2014) investigated the basic internal financial control practices among mosques in the state of Selangor and Wilayah Persekutuan Kuala Lumpur (i.e. the central region of Malaysia). The study suggested that district mosques' internal controls practices on both receipts of income and disbursement of funds require significant attention, particularly the segregation of duties element. Other elements of internal controls, such as physical custody, recording of transactions, and authorization, were at the accepted level in which the majority of mosques in this study have a good practice on that element. For instance, all-district mosques practiced good physical custody for safeguarding the collection boxes by having sealed or locked boxes, and all collection boxes are opened regularly. These could prevent the possibility of theft of the cash collection. Said et al. (2013) argued good internal control and active involvement of mosque 
committees in fundraising activities enhance mosque financial performance, which subsequently influence the quality and quantity of services delivered by mosques.

Undoubtedly, a proper internal control system ensures managers would utilize financial resources in a way that enhances the transparency of mosques in utilising their assets and other resources to meet the organizational objectives (Sulaiman 2007). However, Fahmi (2018) argued that internal controls of mosques are often carried out ineffectively; merely focusing on aspects related to financial information. Internal controls, whereas, should be associated with both financial reporting and disclosure of non-financial information (Alam et al. 2013; Mohamed et al. 2014). Non-financial information, which concerns with strategic decision making commonly reports issues related to sustainability, environmental, social and governance, ethics, human capital, and safety. Transparent information is crucial to inform contributors, donors and endowers on the utilization of the contributions are really for their intended purposes.

On the other hand, the lack of internal controls in mosques on reporting transactions such as receiving income, authorization, recording of financial transactions, and periodic reconciliations would affect the reporting of financial performance (Said et al. 2013). Eliminating the weaknesses or problems in the internal controls is crucial to improve the control over the resources, strengthen accountability, improve financial reporting and the relationship with the stakeholders, thereby enhancing the desire of donors and contributors to continue supporting the religious organizations financially (Mohamed et al. 2014). Highlighting strengths and weaknesses of an internal accounting control system could also allow a set of best practices to improve the system. It is also regarded as a serial process of risk assessment in internal control mechanisms.
The previous studies discussed earlier provide a basis that internal control is without a doubt a very important element in Islamic nonprofit organizations. However, in reality, some organizations may have weak internal controls in place and thus require improvements in their internal control systems.

\section{The Mechanism of Accountability in Nonprofit Organizations (NPOs)}

NPOs have some particular characteristics that distinguish them from profit-making organizations, which means developing an accountability mechanism will be a challenge in these organizations (Mohamed et al. 2014). As a nonprofit organization, it is more dependent upon the external environment for generating financial resources to operate these organizations; government or public at large. Consequently, these nonprofit organizations are accountable to their funders; utilizing the funds to meet the organizational objectives of serving the welfare of the community. This is not without exception to Islamic nonprofit organizations and mosques as religious organizations, in particular, are accountable to appropriate funds received such as infaq, sadaqah, waqf and zakat according to their specific prescriptions or general welfare of the Muslim community. As such, as argued by Basri et al. (2016), Islam strongly encourages a formal accountability mechanism to be practiced, and financial reporting is viewed as an important mechanism in enhancing the accountability of Islamic religious organizations.

Some prior studies of accountability have suggested the mechanism of accountability (Jacobs 2000; Ebrahim 2003; Haque 2000). According to Ebrahim (2003), mechanisms of accountability that are associated with tools and processes, analyzed three dimensions of accountability, including upward-downward, internal-external, and functional-strategic. In nonprofit organizations, Ebrahim (2005) divides accountability mechanisms into five categories, namely reportsand 
disclosure statements; performance assessment and evaluation; participation; selfregulation; and social auditing. In particular, disclosure statements are considered as tools, performance assessment is likely to be a process, self-regulation and participation functioned as both tools and processes, while a social audit is only part of a process.

In the public sector, Jacobs (2000) relies on two accountability mechanisms: the performance of and the financial reporting of public sector organizations. The former relates to internal performance with obligations from the government while the latter is discharged through financial reporting. Therefore, the accountability in this study exhibited the increase of performance in public sector organizations. Furthermore, Haque (2000), who conducted a study on the accountability mechanism of public sector organizations, divides mechanisms into four types, including external-formal mechanisms, external-informal mechanisms, internal-formal mechanisms, and internal-informal mechanism. External-formal mechanisms consist of a relationship between legislative committees and parliamentary questions, administrative courts and ombudsmen, and political control in public agencies. On the other hand, external-informal mechanisms consist of public hearings and interest groups. Internal-formal mechanisms involve rules, codes of conduct, hierarchies, and performance reviews, while internal-informal mechanisms include organizational culture, professional ethics, and peer pressure.

The present study attempts to focus on the internal control practices of nonprofit religious organizations, namely, mosques. Thus, Islamic accountability that explains Islamic organizations are not only accountable to stakeholders, but also God as the creator of nature (Ibrahim 2000) is unique to the mosque as an Islamic organization. This responsibility encourages mosque administrators to always try to help one another in performing their duties and so that the purpose of the mosque can be achieved later. All programs and activities undertaken by mosques are to serve the communities and thus achieve accountability, both to God and the mosque stakeholders.

Therefore, a combination of the accountability mechanism concepts by Haque (2000) and Ebrahim (2003) would allow a more practical evaluation on the existing accountability practices in nonprofit religious organizations. Haque (2000) focused on internal and external accountability, while Ebrahim (2003) discussed the tools and processes within accountability mechanisms. These accountability framework comprising standards, tools, and processes would help to ensure the success of activities and programs in nonprofit religious organizations, including mosques.

This study utilized the accountability mechanisms outlined by COSO Internal Control-Integrated Framework (2013). The internal control framework defines the internal control processes within organizations. These internal control processes would subsequently be used to identify the accountability process. This research attempts to determine the accountability processes in mosques using the accountability mechanisms suggested by Haque (2000) and Ebrahim (2003), which focus on nonprofit and public organizations.

\section{RESEARCH METHODOLOGY}

The study employs qualitative methods of data collection; interviews, and document reviews, to gather information about the selected mosques (Mosque A and Mosque B). The comparative cases provide an opportunity to understand the nature of internal control practices contextually. These two mosques are located in Java, Indonesia. Both mosques are classified as Jami' Mosques, in which the sources of funds come from the community. The mosques are chosen for this study because of their existing diverse activities. These mosques have not only been conducting religious programs but also been undertaking 
Table 1

List of Interviewers

\begin{tabular}{ccll}
\hline No. & $\begin{array}{c}\text { Interviewee } \\
\text { Code }\end{array}$ & \multicolumn{1}{c}{ Position } & Duration \\
\hline 1. & Mr. A01 & The General Treasury of Mosque A & 22 minutes \\
2. & Mr.A02 & The Baitul Mal wat Tamwil Treasury of Mosque A & 18 minutes \\
3. & Mr. A03 & The Secretary of Mosque A & 15 minutes \\
4. & Mr. A04 & The Information and Technology Officer of Mosque A & 30 minutes \\
5. & Mr. A05 & The Deputy Chair of Mosque A & 15 minutes \\
6. & Mr. A06 & The Mosque Youth Officer in Mosque A & 18 minutes \\
7. & Mr. B01 & The Foundation Representative of Mosque B & 50 minutes \\
8. & Mr. B02 & The Deputy Chair of Mosque B & 25 minutes \\
9. & Mr. B03 & The Imarah (prosperous) Officer of Mosque B & 45 minutes \\
10. & Mr. B04 & The Ri'ayah (physical management) Officer of Mosque B & 25 minutes \\
\hline
\end{tabular}

social and economic activities. Social programs provided by these mosques, include distributing breakfast packs to the morning congregations and providing basic foods to the surrounding community. The economic programs in these mosques include capital financing and debt relief programs to the congregations. In addition, Mosque A operates a hotel, an Islamic center, a library, and a health center for the community. Some of these activities generate significant funds for the mosque and thus require an effective management team to ensure these funds are utilized appropriately to benefit the community. Therefore, it is relevant to conduct a case study at these mosques to get insights into their internal control practices.

In gaining access to the case organization, the researcher sent out the request letter through emails to the relationship manager of Mosque A and Mosque B, asking about the possibility of conducting a case study on internal control practices at these mosques with a short description regarding the proposed study. In responding to the emails, the relationship manager forwarded the request letter to the Chief Manager of the mosque. The Chief Manager of Mosque B responded positively and agreed to become a case organization. Furthermore, after doing an interview in
Mosque B, the researcher got a response positively from Mosque A and agreed to become a case organization. An approval from the chief manager of Mosque A and Mosque B was received on $20^{\text {th }}$ December 2019 and $14^{\text {th }}$ January 2020, respectively.

For data collection, the case visit to Mosque A and Mosque B was undertaken from December 2019 to January 2020. The interviews were conducted using semi-structured and open-ended questions. It was to give flexibility to the researcher to explore internal control issues in depth. Semi-structured interviews also allowed the interviewees the freedom to express their ideas on the problems being studied (Horton et al. 2004). The interview protocol was prepared to ensure the interviews stayed on track. The interview protocol consists of a list of questions, information about the interviewees, their positions, and the date and time of interviews.

The interview was conducted with several main personnel in charge of managing the mosques' activities and thus would be able to provide the valid and relevant information required for the study. All relevant personnel from each of the mosques who are involved directly with mosque management and accounting operations were interviewed. The ten interviews were carried out with the chairman, the secretary, the treasurer, an operational 
manager, and the program officers during data collection (Table 5.1). The size of the sample typically relies on the concept of "saturation," or the point at which no new information or themes are observed in the data (Guest et al. 2006). The data saturation in this study is determined if all types of informant characteristics have been represented (Gentles et al. 2015) and the completeness of the overall constructs of the research model is fully represented by the data obtained (Starks et al. 2007).

Besides interviews, some mosques documents and reporting tools were also reviewed. The use of documentary reviews in this study is beneficial to confirm the findings from the interviews. Bryman (2016) classifies four types of documents that support most research, including personal documents, official documents (both public and non-public), mass-media outputs, and virtual documents. The documents reviewed in this study included annual reports, financial statements, organizational profiles, and magazines. Also reviewed in the study are additional documents uploaded at the mosque's website, such as newsletters and brochures. The reason for using multiple sources of data is to allow data triangulation, which could strengthen the validity of data when it reaches data saturation (Shank 2002). Particularly, in a case study, collecting data from multiple sources could improve the contextual validity the findings (Scapens 2004).

In analyzing the data, a thematic network was used in this study. It focuses on identifying, analyzing, and reporting patterns within the collected data (i.e, themes) (Braun and Clarke 2006). This thematic analysis is one of the most commonly used approaches when analyzing qualitative data (Bryman 2016). A qualitative data analysis software, Atlas.ti 8, was used in conducting the thematic analysis. The software was employed to identify key patterns, search for connections between themes, and be more efficient in undertaking the analysis and data management.

\section{CASE FINDINGS: INTERNAL CONTROL PRACTICES OF MOSQUES IN JAVA, INDONESIA}

\section{Control Environment}

Control environment is important to provide the foundation of the internal control' permanence within organizations as it reflects the organizational policies and attitudes. Establishing control environment means creating the rhythm of the organizations; thus, people in the organization are affected to have a consciousness of the importance of control. As a nonprofit organization that the managers are fully volunteering in nature, mosques in Java do not develop a strict regulation like usually carried out by profit-making organizations. They just develop a standard operational procedures (SOP) as a guide to operating mosque activities as the following quote (B01):

"SOPs regulate all activities carried out by the mosque. For example, SOPs to hold studies in mosques. This SOP explained that the material delivered by the cleric must be neutral or impartial to one group. This is intended so that the content provided can be accepted by all congregations and does not offend some of them."

Besides, mosques also apply moral guidance in line with the ethical values that exist in the community. That moral value indirectly regulates the conduct of mosque administrators in carrying out their duties as the quote below (A05):

"In this mosque, we also do all activities based on Islamic values, such as helping each other in carrying out the duties and activities of the mosque."

In general, the organizational structure of mosques in Java is designed according to their needs. There are two models of the organizational structure: centralized or decentralized. In Mosque A, a decentralized organizational structure is practiced, in which every 
bureau has the opportunity to make its program and activities. Also, each bureau manages its budget independently to handle its planned agenda. On the other hand, the organizational structure of Mosque B is centralized in nature, where all of the mosque' activities will only be carried out when approved by the mosque foundation. The managers just simply do the planning of programs and execute them once approved.

\section{Risk Assessment}

Every organization always has a vision and mission to guide their organizational activities. Risk assessment is the way in which organizations handle on how significant each risk is to the achievement of their organizational goals. There are various risk assessment levels within organizations based on the scope of the risk assessment to be undertaken. For mosques in Java, they primarily have two kinds of risk assessment, such as financial statement risk assessment and compliance risk assessment. Financial risk assessment related to a material misstatement of the organization's financial statements. In mosques, this risk is usually caused by internal actions or failures of the organization, particularly people, processes, and systems, for instance, errors in financial records.

In Mosque A, financial risk is mitigated by increasing the number of treasurers. Each bureau has a treasurer apart from a general treasurer of the mosque. This organizational structure aims to minimize the possibility of financial errors because treasurers will supervise each other. A comment by one of its officers (A04):

"The method used to reduce the risk of fraud here is by increasing the number of treasurers. Each bureau has its treasurer so that later among treasurers can supervise each other. Besides, there is also a general treasurer who will later oversee the use of mosque money. “
Furthermore, there are specific procedures for conducting every activity in mosques. Mosque activity will be held if it gets approval from the mosque's team. For example, in the disbursement of mosque' funds, every expenditure has to be approved by three mosques' officers in charge, such as treasurers as related by Officer A01:

"Every decision made is the result of an agreement from the team. The disbursement of funds must be agreed upon by a minimum of three mosque's officials. After that, it was also discussed the use of these funds. After getting approval, it will be executed with the knowledge of other team members."

Similar ly, Mosque B also undertakes compliance risk, which relates to the organization's compliance obligations. An employee of Mosque B violates the standard operating procedure (SOPs), which states that it is forbidden to take any parking fees from congregations. A security guard who asked for such parking fees was finally fired from his job. The existence of a risk assessment is needed so that all mosque activities can be carried out following the SOPs that have been made. It will also encourage the achievement of the goals set by the mosque management.

\section{Control Activities}

Control activities are the policies and procedures implemented by management within organizations and are classified into four categories: segregation of duties, documentation and records, physical control on assets and records, and independence checks on performance. Segregation of duties refers to workforce position within organizations. It is designed to allow any person to complete a task and to prevent abuse (Shim 2011). There are no two or more organizations that are having similar internal control (Morehead 2007). Organizational features like size, structure, 
complexity, purposes, and management philosophy contribute to differences in the controls (Doyle et al. 2006).

There are many different types of segregation of duties between Mosque $\mathrm{A}$ and Mosque B in Java. The segregation structure of duties are distinctively different between these two mosques: Mosque B applies the centralized segregation while Mosque A decentralizes the segregation of duties. In Mosque B, all mosque programs are developed together by the mosque management, and in Mosque A, every bureau has a chief of bureau, secretary, treasurer, and staff that will organize its program.

Furthermore, documentation and records would communicate transactions that occur in organizations to stakeholder form part of the control activities. In Mosque A, financial reports are produced every month. The annual reports are disseminated to the community during Eid al-Fitr, Eid al-Adha, and before the departure of pilgrimage events. Mosque A, however, does not announce the financial statements every Friday, as is usually done by other mosques as mentioned below.

"There are also three annual reports. First, there is a comprehensive report that will be given during Eid al-Fitr. Second, the report was given during Eid al-Adha. Third, the report has given just before the departure of the pilgrimage. So, here (Mosque A) there is no announcement of financial statements conducted every Friday." (A03)

Slightly different from mosque A, the documentation and records of mosque $B$ are shared at all times via digital noticeboard in the mosque, including financial statements. Besides, the mosque also prepares annual documentation and records, which are usually given to congregations during Eid al-Fitr. However, the reports only present information on the activities carried out by the mosque, and there are no financial reports.
Physical checks on assets in both mosques are conducted at varying periods depending on the types of assets. Internal and external auditors usually carry out independence checks on the performance of the ongoing operations in organizations. Independence check is crucial in identifying risks and deals with it (Kamaruddin and Ramli 2017). However, both Mosque A and Mosque B do not have either internal or external auditors. Thus, independence checks are only carried out through supervision by the mosque management.

\section{Information and Communication}

Communication is the process of transferring useful information within organizations either to coordinate activities or to make decisions. Internal communication is done by disseminating information to the people in charge of the organization. In mosques, internal communication is usually done through a regular meeting as related by Officer $\mathrm{A} 05$ below:

"Internal communication is done through informal meetings rather than a formal meeting. The informal meeting is sometimes conducted after the congregational prayers, ... While formal meetings are usually held routinely every three months."

Interestingly, external communication with external parties by Mosque B in Java is executed via social media (B02).

"We carry out external communication through social media owned by the mosque, namely Facebook, YouTube, Telegram, Whatsapp group, and website."

\section{Monitoring Activities}

Monitoring activities have several points of focus, including ongoing monitoring, separate evaluations, and reporting deficiencies. Ongoing monitoring occurs in the ordinary course of operations. In Mosque A 
and Mosque B, ongoing monitoring is performed through CCTV installed in several critical places in the mosque. The installation of CCTV helps to ensure congregations performing their prayers and activities safely and peacefully.

"We perform ongoing monitoring through CCTV in the mosque where there are around 9 CCTVs in the mosque area. The presence of CCTV also helps to maintain the security of mosque equipment and worshipper's belongings". (B02)

A separate evaluation should be undertaken from time to time, focusing directly on system effectiveness. The scope and frequency of separate evaluations depend primarily on assessing risks and ongoing monitoring procedures. In Mosque $\mathrm{A}$, the independent evaluation is usually conducted every day as the mosque' officers live around the mosque.

"Evaluation is usually done at any time because the mosque administrators here are mostly residents here who pray every day here. "

On the other hand, Mosque B usually conducts a separate evaluation, including discussing problems pertaining the mosque after conducting religious programs.

Furthermore, internal control deficiencies should be reported upstream with certain matters reported to top management. The senior management positions for mosques in Java differ according to the types of mosques. As a Jami' mosque, Mosque A has a Syuro Council (Consultative Council) as a supervisor of the mosque's activities. However, in Mosque B, which is under the supervision of a foundation has its top management from the foundation. Besides, senior management also evaluates mosque operation officers and necessary action taken for the non-performing officers as the following quotes (B03):

"For evaluation at any time, because every mosque management has a pro- gram, it must be submitted to the foundation first. So that all programs here will run based on an agreement between mosque management and the foundation. For mosque management, there is no specific period, if the performance is good, it will be maintained, but if it decreases, it will be replaced with another one."

Furthermore, the community also participated in the evaluation process of mosque activities. They will immediately convey to the mosque management about criticism or suggestions for improving mosque activities through the suggestion box.

\section{GENERAL OBSERVATION OF ACCOUNTABILITY PRACTICE IN JAVANESE MOSQUES}

\section{The Media of Communication}

Communication media is an important thing for the whole organization to convey a series of activities to the community. Likewise, for mosques in Java, the communication media has a very important role in conveying information about the activities carried out by the mosque to its congregations. Interestingly, communication media used at mosques in Java include contemporary social media such as Blogs, Whatsapp, Facebook, Instagram, Twitter, Youtube, and Telegram. A comment by one of its officers (B02):

"Besides WA groups, Facebook, Instagram, Twitter, Youtube." (B02)

Information about mosque activities is usually announced on social media, such as Facebook, Instagram, Twitter and Telegram, and WhatsApp Groups. In addition to channeling information on these social media, WhatsApp Groups are usually used to carry out internal communication with mosque administrators. Mosque congregations are also able to convey criticism and suggestions regarding mosque activities via Whatsapp message. 
Furthermore, all routine studies at the mosque will be recorded and uploaded on Youtube to allow congregations and the public to join Islamic studies virtually. In mosque $\mathrm{B}$, there is a digital noticeboard to display information regarding the mosque's programs and financial statements. The digital noticeboards are installed in several strategic locations in the mosque. Screening the financial statements in the digital media can also be interpreted as a form of informal accountability mechanism.

\section{Performance Assessment and Evaluation}

Mosques in Java are conducting performance assessments and evaluations at regular times. This is performed through direct communication with the senior management or foundation of the mosque as the following quotes:

"Direct communication is usually done during routine meetings before Ramadan and annual meetings. The annual meeting is often for performance evaluation." (B02)

"Sometimes, after the congregational prayers, mosque management will gather in the office to discuss the mosque's needs and evaluation. That's usually more effective." (A05)

The statements above explain that the mosque's performance evaluation is formally carried out at the annual meeting, or sometimes informal evaluations are performed after performing congregational prayers. It appears that communication is an effective accountability mechanism. From the above statement too, it can be concluded that informal evaluations are considered more effective as asserted by Mulgan (2000, p.569)

"Accountability is seen to be a" dialectical activity "[which involves an open discussion of matters between organizations and society]."

Otherwise, Mulgan (2000) believes that a dialectical activity is seen as an important part of democracy. This activity requires the organization's management to conduct direct communication for discussing matters that occur within the organization. In other words, accountability is related to explanation and justification, which implies communication between management and society.

Evaluations are conducted so that mosque management can improve its performance and provide the best service to the community. Evaluation is also one of the best mechanisms for the mosque management to discharge its accountability to fund contributors and the public.

\section{The Participation of Management and Community}

Participation in the mosque's management and the community is one of the mechanisms of accountability. Participation of mosque management is important, especially when they take part in mosque activities outside their assigned duties as the quote below (B02):

"There are some mosque's managements who work more. But we choose a coordinator from each field who can control so that all can actively participate. Because the mosque's management position was voluntary, the participation highly depends on their commitment. Those who have a high commitment to their mandate will tend to spend more time in the mosque's programs." (B02)

From the statement above, it can be seen that their level of commitment influences the extent of mosque management participation. In general, the greater the level of commitment, the greater the participation in the mosque activities. Also, the role of the coordinator in each bureau controls the extent of balanced mosque management participation.

Community participation is also needed in the mosque's operational activities, especially in the big events, such as Ramadhan activities, Eid al-Fitr, and Eid al-Adha. Due to the limited number of mosque administrators, 
community participation is needed to arrange the parking areas for those who come to the mosque. The existence of community participation helps to ensure the sustainability of the mosque activities in the future. Another participation from the community is directly involved in determining the structure of the mosque management. The right arrangement of the mosque management will encourage the achievement of the mosque's objectives and also the fulfillment of accountability. In this case, the participation of the community can also determine the accomplishment of mosque accountability.

\section{Self-Regulation}

Regulation is one of the accountability mechanisms in this study. The existing rules at the mosque are Shariah, social norm, government regulation, and standard operational procedures (SOPs), which is made by each mosque. Shariah is guidance in performing religious activities such as prayer and alms, which is based on the Qur'an and Hadith. In general, Shariah will also be used as a guide for Muslims to carry out their activities. Furthermore, social norms are general habits that guide behaviour in a particular group of people. Social norms that apply in each mosque may differ from other mosques because local community agreements determine these social norms. A comment by one of its officers (A05):

"In this mosque, the standard of behaviour is based on Islamic values and social norms." (A05)

The above statement describes that the existence of Shariah law and social norms is primarily used to regulate behavior. This regulation provides guidelines for mosque management to behave following regular habits in the community. With Shariah based guidance, the activities carried out will also be following Islamic teachings. Napier (2007) stated:

"The Islamic concept of social accountability makes it clear that the
Islamic accountant's prime obligation is to the ummah (Islamic community)."

The statement emphasizes that Islamic accountability is a basic obligation that must submit to society. The basic obligation will later shape the value of behavior in Islamic organizations. Furthermore, Ebrahim (2003) also noted:

"The term "self-regulation," as used here, refers specifically to efforts by NGO or nonprofit networks to develop standards or codes of behavior and performance." (819)

The above statement says that an organization also establishes "self-regulation" to stabilize accountability mechanisms. "Selfregulation" is made to complement existing regulations, for example, government regulations. Moreover, the elaboration of the above statement is obviously seen that self-regulation allows nonprofits to develop their codes of behavior and standards of performance. In the mosque context, self-regulation is usually made to regulate the use of mosque funds. Each mosque has a different program so that the use of funds will be following the program being carried out. For instance, in Mosque A, the mosque funds are partly used for charity programs for underprivileged congregations. At the same time, at Mosque B, the mosque funds are also used to provide scholarships for mosque children who are active in mosque activities. Self-regulation can also be one important mechanism for the fulfilment of accountability.

Besides, mosques in Java also apply standard operational procedures (SOP) to regulate all activities carried out by mosque management as the following quotes (B02):

"All activities carried out by the mosque management must also be following standard operational procedures (SOP) that have been made. So that all operations can be controlled properly." (B02)

The existence of SOPs in the mosque is also used to control all activities carried out by 
the mosque management and staff. SOPs also provide guidelines for management and staff to be able to undertake their tasks following established standards. Subsequently, SOPs may be used as a tool to control all mosque activities. As the interviewee said:

"Previous SOP violations have been committed by mosque employee, such as employee cheating, in which employees lack discipline in working hours." (B04)

From the above case, every activity that does not meet the standard will be given a warning or a strict witness under the level of violations that have been committed. SOP is necessary to regulate all activities carried out in the mosque. The application of SOP in mosque activities also encourages accountability in mosque management.

Furthermore, government regulations also become one of the rules that must be obeyed by all mosques in Indonesia. These regulations include guidelines for mosque reporting, specifically mosque financial reporting, and activity guidelines that may be held at the mosque. However, mosques in Java have not made financial reports following government standards, namely the Pernyataan Standar Akuntansi Keuangan (Indonesian Financial Accounting Standard) No. 45 concerning financial reporting of non-profit organizations, because of some reasons. A comment by one of its officers (A01):

"There are still no specific standards followed by this mosque. Because here, the management position as volunteers, if given a heavy burden, will be difficult. We have used the financial reporting system before, but it is hard to implement due to the condition of members whose age is diverse and the skills are not uniformly distributed. That is why, in this time, we still use simple reporting." ( $\mathrm{A} 01)$

The reason why mosques in Java have not implemented financial reporting standards is that mosque managers' position as volunteers (not paid) makes it challenging to give the hard tasks, such as producing a comprehensive financial statement. Besides, the education level from mosque management is uneven, making it difficult to implement comprehensive financial reporting. Therefore, mosques in Java still use simple reporting to report the use of mosque funds. Obeying all applicable rules is also one of the accountability notions which will support organizational development.

\section{Disclosure Statements and Reports}

Disclosure statements and reports are among the most widely used tools of accountability. It is also frequently required by governments in many countries (Ebrahim 2003). Likewise, in Indonesia, the mosque management is expected to develop disclosure statements and relevant reports. In general, there are two reports prepared by mosques in Java: financial statements and activity reports as the following quotes (A05):

"Written reports are made and published once a year, which includes financial reports and activity reports. For financial statements, this mosque only uses simple accounting, which provides income and expense reports. But for some activities, reports are usually made for each activity and will submit to the mosque's secretary." (A05)

The financial report contains a cash flow statement, which reports the income and expenditure of the mosque. The financial reports of both Mosque A and Mosque B are still using simple accounting methods. It is due to the laxity in the management ability to prepare a comprehensive financial report on the use of mosque funds in each program. The activity report explains what the mosque management has held activities. Each year, Mosque A and Mosque B produced annual reports in the form of a bulletin and distributed to their congregants. At Mosque A, the bulletin consisted 
of financial reports and mosque activity reports, while in Mosque $B$, the bulletin only contains reports on mosque activities. Mosque B's financial statements are published on the digital notice board in the mosque as the quote below (A04):

"To maintain accountability, one way to do that is by distributing 2500 bulletins to mosque worshipers during Eid. The bulletin contains activity reports and financial reports from the mosque." (A04)

Bulletins are usually distributed during special events, like Eid Al-Fitr when the public would come and pray at the mosque. The relevant stakeholders would be able to learn the use of funds contributed by them. Furthermore, distributing bulletin is also a form of upward accountability from mosque management to stakeholders, especially donors. Being transparent in the use of mosque funds could increase the community's trust in mosque administrators (Sulaiman 2007).

\section{CONCLUSION}

The objective of this research is to explore and investigate the internal control practices of mosques in Java. The internal control practices are subsequently used to identify accountability mechanisms in the two selected mosques. This study has identified the internal control practices and accountability mechanisms of the two selected mosques in Java.

Every mosque has different activities in delivering services to the community, and this shapes the varying internal control practices of the mosque. As in this study, Mosque A, as a community mosque has more activities as compared to Mosque $\mathrm{B}$, which is a foundation mosque. In terms of the control environment, mosques in Java seem do not develop strict regulations, although there are SOPs to control their activities. The SOPs are applied based on the ethical values prevailing in the community. Meanwhile, the risk assessment of mosques in Java is found to comprise financial risk assessment and compliant risk assessment.

In addition, control activities have existed as part of the normal operating activities in mosques. The notion of control activities of mosques in Java includes segregation of duties, authorization of transactions, documentation and records, physical control over assets and records, and independent checks on performance. Reporting of information and communication is another internal control process in the mosques. Internal communication is performed over the mosque's meetings, while the external communication is commonly done via the mosque' social media platforms. These mosques also do monitoring activities such as ongoing monitoring, separate evaluations, and reporting deficiencies regularly. Consequently, these mosques appear to have achieved their goals, implying that internal control practices may influence the accountability process in the mosques.

Internal control processes in mosques of Java have a substantial influence on the accountability processes. There are five accountability mechanisms commonly practiced by mosques in Java. First, communication media such as social media and digital noticeboards are common tools to convey information about programs and financial reports of mosques to the public. Second, performance assessment and evaluation are carried out to improve the performance of mosque management. Evaluations are usually carried out during routine meetings conducted by mosque management and direct communication performed informally by the mosque management. Third, the commitment of the mosque management and community participation determines the success of all mosque programs. Fourth, self-regulation becomes an important accountability mechanism in mosques. The regulations used as guidelines for mosque management in carrying out all mosque activities include the Shariah laws, social norms, government regulations, and 
standard operational procedures (SOP) developed by each of the mosques. Fifth, disclosure statements and reports are widely used as an accountability mechanism. In general, reports prepared by the mosques include activity reports and financial reports containing details of all receipts and uses of mosque funds.

These mechanisms in both formal and informal forms are driving the achievement of accountability in the mosques. For example, formal accountability mechanisms during program preparation activities by mosque management show the form of professionalism of mosque management in carrying out their duties. Preparing and distributing mosque reports for mosque stakeholders are a formal accountability mechanism. More importantly, Islamic accountability, which is unique to Islamic organizations including the mosques necessitates accountability to both God as the creator of nature and other stakeholders. This accountability drives mosque administrators to always perform their duties effectively in delivering services to the community, as the main stakeholder of mosques.

The study acknowledges the selection of interviewees as its limitation. The selected interviewees in this study are limited to only two mosques in Java. Therefore, the results should be interpreted in context and should not be generalized to other mosques in Java or Indonesia. Therefore, the study has some suggestions for future research in the area. Firstly, since this study is conducted in Java mosques, future researches may be conducted in other cities or provinces in Indonesia to provide different internal control perspectives. Secondly, comparative studies may be performed between Muslim countries in the Asian region, for example, Indonesia and Malaysia. Finally, future studies in internal control practices may be conducted in other Islamic organizations, such as zakah management center or the institutions of waqf (endowment funds) and the Baitul Mal (the public treasury).
More importantly, this study contributes to an understanding of internal control practices of mosques in Java. This study illustrates that mosques in Java do not fully comply with the government's regulations, such as Pernyataan Standar Akuntansi Keuangan (Indonesian Financial Accounting Standard) No 45 related to reporting standard of non-profit organizations, due to the lack of networking, awareness and competency among members of the mosque management. In summary, the findings are expected to provide a guideline to the regulators of mosques in Indonesia in the development and implementation of the internal control practices in all mosques throughout Indonesia.

\section{REFERENCES}

Agoes, S. 2012. Auditing: Petunjuk Praktis Pemeriksaan Akuntan oleh Akuntan Publik. Jakarta: Salemba Empat.

American Institute of Certified Public Accountants [AICPA]. 1994. American Institute of Certified Public Accountants [AICPA] Professional standards. New York, NY, US: AICPA.

Association of Certified Fraud Examiners (ACFE). 2018. Report to the nations on occupational fraud \& abuse: 2018 global fraud study. Retrieved from https://www.acfe.com/rttn2018

/docs/2018-report-to-the-nations.pdf.

Basri, H., A. K. S. Nabiha, and M. S. A. Majid. 2016. Accounting and Accountability in Religious Organizations: An Islamic Contemporary Scholars 'Perspective. 18 (2), 207-230.

Bongani, N. 2013. Application of Internal Controls in NGOs: Evidence from Zimbabwe. 1(2), 39-47.

Braun, V., and V. Clarke. 2006. Using Thematic Analysis in Psychology. Qualitative Research in Psychology, 3(2), 77-101.

Bryman, A. 2016. Social Research Methods (5th ed.). United Kingdom: Oxford University Press. 
COSO. 2013. Committee of Sponsoring Organizations of the Treadway Commission. Framework \& The 2013 SOX Compliance. 1-74.

Doyle, J., T. Street, and S. Mcvay. 2006. Determinants Of Weaknesses In Internal Control Over Financial Reporting And The Implications For Earnings Quality. In Internal Control over Financial Reporting. Journal of Accounting and Economics, 44 (1), 193-223.

Ebrahim, A. 2003. Accountability in practice: Mechanisms for NGOs. World Development.

Ebrahim, A. 2005. Accountability myopia: Losing Sight of Organizational learning. Nonprofit and Voluntary Sector Quarterly.

Fahmi, R. A. 2018. Enhancing the Economic Role of the Mosque through Empowerment a Case Study in Yogyakarta City.

Gentles, S. J. et al. 2015. Sampling In Qualitative Research: Insights From An Overview Of The Methods Literature. Qualitative Report, 20 (11), 1772-1789.

Greenlee, J. et al. 2007. Nonprofit and Voluntary Sector Quarterly Deterrents. (August 2014).

Guest, G., A. Bunce, and L. Johnson. 2006. How Many Interviews Are Enough?: An Experiment with Data Saturation and Variability. Field Methods, 18 (1), 5982.

Hall, B. H. 2002. The Financing of Research and Development. (January).

Haque, M. S. 2000. Significance Of Accountability Under The New Approach To Public Governance. International Review of Administrative Sciences, 66(4), 599-617.

Horton, J., R. Macve, and G. Sruyven. 2004. Qualitative Research; Experiences In Using Semi-Structured Inverviews", in Humprey, C and Lee, B.H.K.(Eds). In The Real Life Guide to Accounting Research: A Behind the Scenes View of
Using Qualitative Research Methods (339-357). Amsterdam: Elsevier.

Jacobs, K. 2000. Evaluating accountability: finding a place for the Treaty of Waitangi in the New Zealand public sector. 13(3), 360-380.

Kamaruddin and N. Ramli. 2017. A Case Study of Internal Control Practices in Islamic Non-Profit Organisations in. (November).

Kummer, T., K. Singh, and P. Best. 2014. The Effect of Fraud on Risk Management in Not-for-Profit Organizations. 12(1), 641-655.

Lam, L. 2020. Woman Gets Jail For Embezzling $\mathrm{S} \$ 38,000$ From Mosque Over More Than 2 Years. Retrieved from https://www.channelnewsasia.com/news /singapore/woman-gets-jail-forembezzling-s-38-000-from-mosqueover-more-12242818

Masrek, M. N. et al. 2014. Internal Financial Controls Practices of District Mosques in Central Region of Malaysia. 5 (3), 3 6.

McKeever, B. 2018. The Nonprofit Sector in Brief 2018. Retrieved August 20, 2020, from https://nccs.urban.org/publication/nonpr ofit-sector-brief-2018\#the-nonprofitsector-in-brief-2018-public-charitesgiving-and-volunteering

Mintzberg, H. 1989. The Manager's Job : The Classical View Says That The Manager Organizes. 12-20.

Mohamed Adil, M. A. et al. 2013. Financial Management Practices of Mosques in Malaysia. 3(1), 23-30.

Mohamed, I. S. et al. 2014. Mosque Fund Management: Issues on Accountability and Internal Controls. Procedia - Social and Behavioral Sciences.

Mohamed Ibrahim, S. H. 2000. The need for Islamic accounting: perceptions of its objectives and characteristics by Malaysian Muslim accountants and accounting academics. 
Morehead, W. A. 2007. Internal Control and Governance in Non-Governmental Organizations Designed to Provide Accountability and Deter, Prevent and Detect Fraud and Corruption. The University of Southern Mississippi.

mstar.com. 2016. SPRM Buka 35 Kertas Siasatan Penyelewengan Karpet Masjid, Surau. Retrieved March 10, 2020, from https://www.mstar.com.my/lokal/semas $\mathrm{a} / 2016 / 10 / 27 /$ sprm-penyelewengankarpet

Mulgan, R. 2000. 'Accountability': an EverExpanding Concept? Public Administration Journal, 78 (3), 555-573.

Napier, C. 2007. Other cultures, other accountings.pdf. 44 (0), 9-11.

Padmasari, S. E. 2018. Terlibat Kasus Korupsi Dana Hibah, Ketua Yayasan Masjid Agung Palopo Ditahan. Retrieved March 10, 2020, from https://www.merdeka.com/peristiwa/terl ibat-kasus-korupsi-dana-hibah-ketuayayasan-masjid-agung-palopoditahan.html

Pratama, D. B. 2019. Tersangka Pungli Dana Rekonstruksi Masjid NTB Dijerat Pasal Berlapis. Retrieved from https://www.antaranews.com/berita/788 198/tersangka-pungli-danarekonstruksi-masjid-ntb-dijerat-pasalberlapis\%0D

Rachman, D. A. 2019. KPK Supervisi Kasus Dugaan Korupsi Pembangunan Masjid Agung Melawi. Retrieved from https://nasional.kompas.com/read/2019/ 07/25/13442551/kpk-supervisi-kasusdugaan-korupsi-pembangunan-masjidagung-melawi\%0D

Said, J. et al. 2013. Financial Management Practices in Religious Organizations: An Empirical Evidence of Mosque in Malaysia. 6(7), 111-119.

Scapens, R. 2004. Doing Case Study Research.

Seyam, Y. et al. 2018. An Overview of Fraud in Nonprofit Organizations and the
Appropriate Approach to Prevent It. 1(2).

Shank, G. 2002. Qualitative Research: A Personal Skills Approach. Merril Prentice Hall, Upper Saddle River.

Shim, K. J. 2011. Internal Control and Fraud Detection. Global Professional Publishing Limited.

Starks, H., S. B. Trinidad. 2007. Choose Your Method: A Comparison Of Phenomenology, Discourse Analysis, And Grounded Theory. Qualitative Health Research, 17 (10), 1372-1380.

Sulaiman, M. 2007. The Internal Control Procedures of Mosques in Malaysia. Revista Universo Contabil, 3, 101-115.

Tarigan, N. E., and B. W. Saputra. 2013. Peran Internal Auditor terhadap Efektifitas Pengendalian: Internal Process Credit Granting and Collection. Finance and Accounting Journal, 2 (1), 68-89. 